
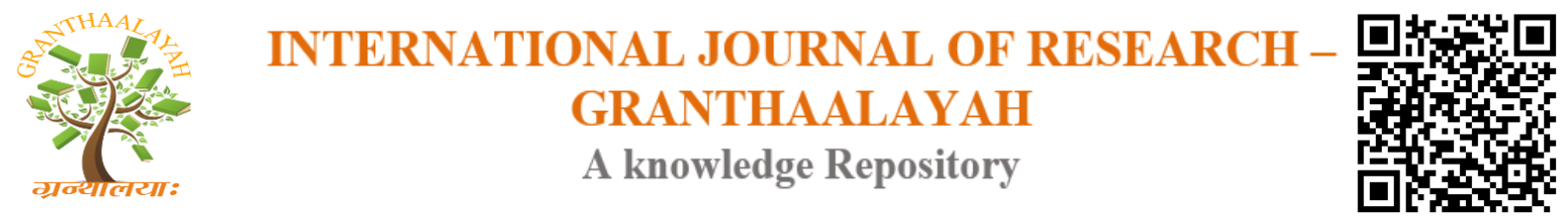

Management

\title{
A STUDY ON THE ISSUES AND PROBLEMS OF WOMEN ENTREPRENEURS IN KERALA WITH SPECIAL REFERENCE TO MALAPPURAM DISTRICT
}

\author{
Unnikrishnan.P ${ }^{* 1}$, S.Bhuvaneswari ${ }^{2}$ \\ ${ }^{* 1}$ M.Phil Scholar, Sree Narayana Guru College, Coimbatore, INDIA \\ 2 Asst. Professor, Sree Narayana Guru College, Coimbatore, INDIA
}

DOI: https://doi.org/10.29121/granthaalayah.v4.i9.2016.2542

\section{ABSTRACT}

The entrepreneurs play an important role in the economic and social development of the nation. Women entrepreneurs are also giving a partial role in this field. Now a day, society gives a better socio economic status to women. The State and Central Government has been introduced various schemes and empowerment programs to promote them to sustain in good working conditions of women enterprise.

At present, the number of women entrepreneurs in Kerala is low. If the Government takes necessary promotional measures, the number will rise into an indefinite in future and they can contribute much for the entrepreneurial growth of Kerala. Mostly the women are producing home need items, and this type of essentials \& food items. These opportunities can be further applied for the growth of Kerala's entrepreneurship and the future of women entrepreneur will be an asset for the growth of our state. This study helps to find out the various problems faced by women Entrepreneurs in Malappuram District. The details are directly collected from women entrepreneurs to observe their problems.

Keywords:

Women Entrepreneurs, Entrepreneurs, Economic, Social Development.

Cite This Article: Unnikrishnan.P, and S.Bhuvaneswari, "A STUDY ON THE ISSUES AND PROBLEMS OF WOMEN ENTREPRENEURS IN KERALA WITH SPECIAL REFERENCE TO MALAPPURAM DISTRICT" International Journal of Research - Granthaalayah, Vol. 4, No. 9 (2016): 105-112.

\section{INTRODUCTION}

The entrepreneur is a key to economic development. Evolution of the concept of entrepreneurship was only in the beginning until 18th century. The word entrepreneur is derived from the French word 'Entreprendre' which means 'to undertake'. Thus entrepreneur is a person who undertakes the risk of a new enterprise. 
In the words of Robert E Nelson, "an entrepreneur is a person who is able to look at the environment, identifying opportunity to improve the environment, marshal resources and implement action to maximize those opportunities."

The emergence of women entrepreneurs in a society depends, to a great extent, on the economic, religious, cultural, social, psychological and a host of other factors. To developing countries like India, the presence of entrepreneurs, that too women entrepreneurs is a vital necessity to achieve a rapid, all around and regionally and socially balanced economic growth through industrialization. It also helps in tapping the inherent talent prevailing among them and acts as a panacea for many problems faced by them such as dowry death, low recognition in society, poverty, and unemployment and excessive dependence on male members. There is greater dynamism in the rate of growth of female employment. The emergence of women entrepreneurs is to be viewed as socio-economic emancipation of women.

\section{OBJECTIVES OF THE STUDY}

1) To study the problems in starting and running women entrepreneurship in Malappuram District

2) To study whether adequate promotional schemes are offered by Government for women entrepreneurs.

3) To study the method by which women entrepreneurs are raising funds.

4) To study the attitude of family and others towards women entrepreneurs in Malappuram District.

5) To check whether adequate training and marketing facilities are available for women entrepreneurs in Malappuram District.

6) To analyze socio-economic status of women entrepreneurs in Malappuram District.

7) To provide suggestion for the improvement for the functioning of women enterprise.

\section{RESEARCH METHODOLOGY}

\section{SAMPLE SIZE}

The sample size was fixed to 125 women entrepreneurs in Malappuram District.

\section{SAMPLING METHOD}

'CONVENIENT' sampling method is used for this study

\section{SOURCE OF DATA}

For this study both primary and secondary data are used. Primary data are collected directly from 125 women entrepreneurs in Malappuram District. Secondary data are collected from journals and publications, books, relevant website etc. 


\section{TOOLS FOR DATA COLLECTION}

Primary data were collected through direct discussion and interview. For collection of information from women entrepreneurs, questionnaire and interview schedule were used.

\section{TOOLS FOR ANALYSIS}

Simple percentage method and weighted ranking method are used for analyzing the collected data

\section{ENTREPRENEUR}

According to E.E.Hagen, "an entrepreneur is an economic man who tries to maximize his profits by innovation, involve problem solving and gets satisfaction from using his capabilities on attacking problems".

M.M.P.Akhouri (formerly Executive Director, NIESBUD) describes entrepreneur as "a character who combines innovativeness, readiness to take risk, sensing opportunities, identifying and mobilizing potential resources, concerns for excellence and who is persistent in achieving goal".

\section{ENTREPRENEURSHIP}

According to A.H.Cole "entrepreneurship is the purposeful activity of an individual or a group of associated individuals, undertaken to initiate, maintain or aggrandize profit by production or distribution of economic goods and services".

\section{WOMEN ENTREPRENEURSHIP}

According to the general concept, women entrepreneur may be defined as a woman or a group of women, who initiate, organize and operate a business enterprise.

The Government of India has defined a woman entrepreneurship as "an enterprise owned and controlled by a woman having a minimum financial interest of $51 \%$ of the capital and giving at least $51 \%$ of the employment generated in the enterprise to women"

\section{FEATURES OF WOMEN ENTREPRENEURSHIP}

\section{1) Management and control:}

A woman or a group of women manages the whole business of enterprise. She prepares various plans and executes them under her own supervision and control. There may be some person to help her but ultimate control lies with the women.

\section{2) Employment to women:}

A woman entrepreneur must provide at least $51 \%$ of the employment granted in her enterprise to women.

\section{3) Risk-taking:}

Risk means uncertainty. It is the condition of not knowing the outcome of an activity. A woman entrepreneur takes calculated risk. She faces uncertainty confidently and assumes risk. She has to 
tie up capital and wait for good likes to take realistic risks because she wants to be a successful entrepreneur.

4) Good organizer:

The most critical skill required for industrial development is the ability of building a sound organization. A woman entrepreneur assembles, co-ordinates, organizes and manages various factors namely land, labour and capital. She obtains factors of production from the society and supplies them as finished products.

5) Self-confidence:

It is essential to be self-confident for a woman entrepreneur. She should have faith in herself and in her abilities. She should have the confidence to implement the changes and overcome any resistance to change. A woman entrepreneur should have courage to own the mistakes and correct them.

6) Decision maker:

The main function of a woman entrepreneur is to make decision. She takes various decisions regarding the activities of her enterprise. She decides about the types of business to be done and the way doing it. A women entrepreneur must be clear and creative in decision making process.

7) Hard worker:

A distinguishing feature of a woman entrepreneur is the willingness to work hard. She has to follow the principle, "Hard work is the key to success".

\section{PROBLEMS OF WOMEN ENTREPRENEURS}

\section{1) Problem of Finance:}

Finance is regarded as "life-blood" for any enterprise, be it big or small. However, women entrepreneurs suffer from shortage of finance on two counts. Firstly, women do not generally have property on their name to use them as collateral for obtaining funds from external sources. Thus, their access to the external source of fund is limited. Secondly, the bank also considers women are less credit-worthy and discourage women borrowers on the brief that they can at any time leave their business.

\section{2) Scarcity of Raw Material:}

Most of the women enterprises are plagued by the scarcity of raw material and necessary inputs

3) Stiff Competition:

Women entrepreneurs do not have organizational set-up to pump in a lot of money in canvasing and advertisement. Thus, they have to face a stiff competition for marketing their products with both organized sector and their male counterparts. Such a competition ultimately results in the liquidation of women enterprises.

\section{4) Family Ties:}

Family problems are important barriers for the success of women entrepreneurship. Lack of family support and social support discourage women in starting and running enterprises.

\section{5) Lack of Education:}

In India, around three-fifth $(60 \%)$ of women are still illiterate. Illiteracy is the root cause of socio-economic problems. Due to the lack of education and that too qualitative education, women are not aware of business, technology and market knowledge. Also lack of education causes low achievement, motivation among women. 
6) Male-Dominated Society:

Male dominism is still the order of the day in India. The constitution of India speaks of equality between sexes. But, in practice, women are looked upon as weak in all respects. In the male dominated Indian society, women are not treated equal to men. This, in turn, serves as a barrier to women entry into business.

7) Low Risk-Bearing Ability:

A woman in India leads a protected life. They are less educated and economically not selfdependent. All these reduce their ability to bear risk involved in running an enterprise. Riskbearing is an essential requisite for a successful entrepreneur.

8) Heavy Competition:

Many of the women enterprises have imperfect organizational set up. But they have to face severe competition from organized industries.

In addition to above problems, inadequate infrastructural facilities, shortage of power, high cost of production, social attitude, low need for achievement and socioeconomic constraints also hold the women back from entering into business.

\section{REMEDIES TO OVERCOME THE PROBLEMS}

\section{1) Creation of finance cells:}

The financial institutions and banks which provide finances to entrepreneurs must create special cells for providing easy finance to women entrepreneurs.

\section{2) Concessional Rates of Interest:}

The women entrepreneurs should be provided finance at concessional rate of interests and on easy repayment basis. The cumbersome formalities should be avoided in sanctioning the loans to women entrepreneurs.

3) Proper Supply of Raw Materials:

Women entrepreneurs should be ensured of proper supply of scarce raw materials on priority basis. A subsidy may also be offered to make the products manufactured by women entrepreneurs to make the cost competitive and reasonable.

4) Offering Training Facilities:

Training is essential for the development of entrepreneurship. It enables the women entrepreneurs to undertake the venture successfully as it imparts required skills to run the enterprise.

5) Industrial Policies:

The new industrial policy of government has specially highlighted the need for conducting special entrepreneurship programme for women.

6) Institutions and Voluntary Association:

Several voluntary agencies like FICCI Ladies Organization (FLO), National Alliance of Youth Entrepreneurs (NAYE) and others assist women entrepreneurs.

NAYE has the leading institution engaged in the promotion and development of entrepreneurship among women. It convened a conference of women entrepreneurs in November 1975. It assists women entrepreneurs in:

- Getting better access to capital, infrastructure and market.

- Identifying investment opportunities.

- Developing managerial and productive capabilities. 
- Attending to problems by taking up individual cases with appropriate authorities.

- Sponsoring participation in trade fairs, exhibitions, special conferences etc.

7) Setting up Marketing Co-operatives:

Proper encouragement and assistance should be provided to women entrepreneurs for setting up marketing co-operatives. These co-operatives shall help in getting the input at reasonable rate and they are helpful in setting their products at remuneration prices.

\section{ORGANIZATIONS PROMOTING WOMEN ENTREPRENEURSHIP IN INDIA}

\section{1) National Resource Centre for Women (NRCW)}

An autonomous body set up under the National Commission for Women Act, 1990 to take up women's issues, facilitate leadership training and to create a national database in the field of women's development.

2) Women's India Trust (WIT)

WIT is a charitable organization established in 1968 to develop skills of women and to earn a regular income by providing training and employment opportunities to the needy and unskilled women of all communities in and around Mumbai.

3) Development of Women and Children in Urban Area (DWCUA)

DWCUA was introduced in 1997 in order to organize the urban poor among women in socioeconomic self-employment activity groups with the dual objective of providing self-employment opportunities and social strength to them.

4) Association of Women Entrepreneurs of Karnataka (AWAKE)

AWAKE was constituted by a team of women entrepreneurs in Bangalore with a view to helping other women in different ways - to prepare project report, to secure finance, to choose and use a product, to deal with bureaucratic hassles, to tackle labour problems, etc.

5) Working Women's Forum (WWF)

WWF was founded in Chennai for the development of poor working women to rescue petty traders from the clutches of middlemen and to make them confident entrepreneurs in their own right. The beneficiaries are fisher women, lace makers, beedi making women, landless women, labourers and agarbathi workers.

6) Association of Women Entrepreneurs of Small Scale Industries (AWESSI)

It was founded in Ambattur in Chennai in 1984 to promote, protect and encourage women entrepreneurs and their interests in South India to seek work and co-operate with the Central and State Government services and other Government agencies and to promote measures for the furtherance and protection of small-scale industries.

7) Women's Occupational Training Directorate

It organizes regular skill training courses at basic, advanced and post advanced levels. There are 10 Regional Vocational Training Institutes (RVTIs) in different parts of the country, besides a National Vocational Training Institute (NVTI) at NOIDA.

8) Self- Employed Women's Association (SEWA)

SEWA is a trade union registered in 1972. It is an organization of poor self- employed women workers. SEWA's main goals are to organize women workers to obtain full employment and self- reliance.

9) Self- Help Group (SHG)

An association of women, constituted mainly for the purpose of uplifting the women belonging to the Below Poverty Line (BPL) categories to the Above Poverty Line (APL) category. The 
major activities of the group are income generation programmes, informal banking, credit, unions, health, nutritional programme, etc.

\section{ANALYSIS AND INTERPRETATIONS}

Table 1: Table Showing Various Promotional Benefits Availed by Women Entrepreneurs

\begin{tabular}{|l|l|l|}
\hline BENEFITS & NO. OF RESPONDENT & PERCENTAGE \\
\hline Grand & 26 & 20.8 \\
\hline Subsidy & 8 & 6.4 \\
\hline Concession & 16 & 12.8 \\
\hline Others & 12 & 9.6 \\
\hline No benefits & 63 & 50.4 \\
\hline Total & 125 & 100 \\
\hline
\end{tabular}

Table 2: Table Showing Whether Adequate Marketing Facilities are Available for Selling the

\begin{tabular}{|l|l|l|}
\hline OPINION & NO. OF RESPONDENT & PERCENTAGE \\
\hline Always & 66 & 53 \\
\hline Sometimes & 56 & 45 \\
\hline Never & 3 & 2 \\
\hline Total & 125 & 100 \\
\hline
\end{tabular}

Table 3: Table Showing Whether the Respondents Faced any Marketing Competition

\begin{tabular}{|l|l|l|}
\hline OPINION & NO. OF RESPONDENT & PERCENTAGE \\
\hline Yes & 80 & 64 \\
\hline No & 45 & 36 \\
\hline Total & 125 & 100 \\
\hline
\end{tabular}

Table 4: Table Showing Various Problems Faced by Women Entrepreneurs

\begin{tabular}{|l|l|l|}
\hline PROBLEMS & NO. OF RESPONDENT & PERCENTAGE \\
\hline Inadequate infrastructure facility & 9 & 7 \\
\hline Lack of skilled labour & 17 & 14 \\
\hline Non availability of raw material & 13 & 10 \\
\hline Lack of training & 5 & 4 \\
\hline Marketing problem & 16 & 13 \\
\hline Inadequate finance & 48 & 38 \\
\hline lack of govt. support & 17 & 14 \\
\hline Total & 125 & 100 \\
\hline
\end{tabular}

\section{FINDINGS OF THE STUDY}

1) Majority (82\%) of respondents says that no financial benefits and no promotional benefits availed from Government for starting and running unit.

2) It is found that majority $(33 \%)$ of respondents are dissatisfied with the attitude of Government 
3) Majority (56\%) of respondents says that attitude of local self-Government is bad.

4) It is found that majority (38\%) of respondent faced problem of inadequate finance.

$5)$ It is found that majority (34\%) of respondents are getting training from private agency.

6) Majority (73\%) of respondents says that attitude of natives is good.

7 ) It is found that majority $(64 \%)$ of respondents are facing marketing competition.

8) It is found that majority (77\%) of respondents are adopting direct marketing channels.

9) Majority (50\%) of respondents says that sometimes only they are getting reasonable price for their products.

10) It is found that majority (37\%) of respondents agree that Government is now taking adequate measures for the development of entrepreneurship in Kerala.

\section{SUGGESTIONS FOR IMPROVEMENT}

1) Government and financial institutions should provide special assistance and incentives for encouraging women entrepreneurship.

2) Proper training shall be given to the women entrepreneurs through Government Programmes.

3) Many people are not aware about available entrepreneurial opportunities, though the Government is offering different types of incentives and assistance; still many people are beyond purview. There is a dire need to create awareness about entrepreneurial opportunities assistance.

4) More research is to be conducted to identify the problem which is being faced by women entrepreneurs.

5) Women industrial estate shall be setup in each District for upgrading level of activities of women entrepreneurs.

6) Wide publicity should be given about the financial assistance and other incentives that are offered by the Government

7) Co-operative institution and Banks use a share of their profit for the promotion of women entrepreneurs by providing free training, loans with subsidy, and loan without interest for helping them to identify suitable products under their jurisdiction.

8) The Government assistance should be given in the areas like marketing, distribution etc. of the Women entrepreneurship products.

\section{REFERENCES}

[1] Entrepreneurship development, A.Vinod, Calicut university publications.

[2] Entrepreneurship development, E.Gorden \& K.Natarajan,Himalaya publications

[3] Entrepreneurial development, Dr.S.S.Khanka, s.chand publications

[4] Entrepreneurial development, Dr.C.B.Gupta \& Dr.N.P.Srinivasan, s.chand publications

[5] Prabandhan : indian journal of management, vol 7(2), feb 2014

[6] Prabandhan : indian journal of management, vol 7(5), may 2014

[7] Epra international journal of economic and business review

[8] International journal of social science research 